\title{
The Influence Ultraviolet Light and Scent Therapy for Reducing Germs Pulmonary Tuberculosis
}

\author{
Zainul Ikhwan ${ }^{1}$, Rina Madhona ${ }^{2}$ \\ ${ }^{I}$ Envirotmental Health Study Program, Health of Tanjungpinang, Indonesia \\ zainul.ikhwan@gmail.com \\ ${ }^{2}$ University of Sumatera Utara, Indonesia \\ rinamadhonaegmail.com
}

\begin{abstract}
In Tanjungpinang, the incidence of pulmonary TB is still quite high. In 2011 as many 2,536 as suspected pulmonary TB positive cases examined and 216 as patients. In 2012 have been examined as many as 2,065 patients with chronic cough sputum specimens. The total positive from smear positive bacteria is 184 specimens. (District Health Office of Tanjungpinang, 2012). Pulmonary tuberculosis is a communicable disease which is caused by Mycobacterium tuberculosis which can live up to several hours in the dark and damp but will die when exposed to ultraviolet light. The purpose of this study is known UVC-Aromatherapy therapeutic effect against germs decreased levels of $\mathrm{Tb}$ in positive patients with pulmonary $\mathrm{Tb}$. This research is an experimental research with pre-experimental design one group pre-test-post-test. The subjects and object of this research were positive pulmonary TB patients as cases and UVC-Aromatherapy. The analysis was conducted by the Mann-Whitney Test with a confidence level of $\alpha=0.05$. The analysis can be significant difference UVCaromatherapy treatment against impairment of the germs $\mathbf{T b}$ Lung Positive Patients $(p=0,026)$. UVC-Aromatherapy can be used as a form of treatment Positive Patients with Pulmonary $\mathrm{Tb}$, which can sync yours with pulmonary $\mathrm{Tb}$ program in the Department of Health. Minimize dependency on the use of drugs and prevent dropouts and resistance problems.
\end{abstract}

Keywords - Pulmonary TB, UVC-Aromatherapy

\section{INTRODUCTION}

Tuberculosis (TB) is a chronic infectious disease caused by the bacterium Mycobacterium tuberculosis. Most of the TB bacteria invade the lungs; there is also attacking other body parts such as bones, glands, and brain commonly called extrapulmonary TB [1] Additional environmental control measures are urgently needed. Tuberculosis (TB) infection control remains a public health priority, especially with the emergence of extensively drugresistant strains [2] TB outbreaks have long been reported in congregate settings [3] including hospitals [4] and correctional facilities [5]. Guidelines for preventing TB transmission in health care settings advocate administrative control measures to ensure prompt diagnosis, isolation, and treatment of TB patients; environmental control measures to reduce the concentration of airborne infectious droplet nuclei; and personal respiratory protection [6]. Environmental control measures such as negative pressure mechanical ventilation are expensive to install and maintain and offer limited protection [7]. Natural ventilation may provide greater protection for little cost [8], but is climate dependent.

In Indonesia, $\mathrm{TB}$ is a major public health problem. In 2010, the number of TB cases in Indonesia ranks fourth in the world after India, China, and South Africa, with the number of cases around 0.37 million- 0.54 million [9]. Based on the results of Health Research Riskesdas in 2010, Period Prevalence of pulmonary TB in the population aged 15 years and over 2009/2010 is based on the diagnosis of health workers through examination of sputum and lung or photos of $725 /$ 100,000 populations [10]. Figures in Riau Islands province with pulmonary tuberculosis with smear positive improvements, which in 2011 amounted to 1,033 cases and in 2012 the numbers increased to 1,097 cases [11]. In the city of Tanjungpinang incidence of pulmonary TB is still quite high. In 2011 as many as 2,536 suspected pulmonary TB smear positive cases examined and that as many as 216 patients. The year 2012 has been examined as many as 2,065 patients with chronic cough sputum specimens. The total positive from smear positive bacteria is 184 specimens. [12].

Every year, the number of pulmonary TB patient is always there. In addition, the quarterly report in Tanjungpinang always found pulmonary tuberculosis patients even though no cases of outbreaks (Extraordinary Events). Smear positive 
pulmonary tuberculosis patients can be a source of infection. Ultraviolet-C is very effective for killing bacteria and virus Mycobacterium tuberculosis (TB), Legionella pneumophila (Legionnaire's Diseases), and other microbe particles that exist in the air. This ray wavelength is between $190 \mathrm{~nm}$ to $280 \mathrm{~nm}$. It is not too long so that the earth is protected by it. Most UVC rays would be lost in the ozone layer. Otherwise, we could feel the negative impact was so great because these rays are most dangerous. As a modern man concerned about health and beauty, we have to prevent skin damage from exposure to ultraviolet light. Noting the above problems, researchers are interested in raising the issue in research with the aim of UVC Aromatherapy as a solution to problems of TB.

\section{METHODS}

This research is an experimental research with pre-experimental design one group pre-test-posttest. The subjects and object of this research were positive pulmonary TB patients as cases and UVCAromatherapy. The analysis was conducted by the Mann-Whitney Test with a confidence level of $\alpha=$ 0.05 .

Patient Recruitment with pulmonary TB was admitted to the negative-pressure room sand invited to join the study with written informed consent. Patient admission, management, or duration of hospital stay was influenced by the study. Sputum smear-positive patients were preferentially located in the study rooms, from which air passed to the airsampling facility on the roof. UV Lights An upward-facing UV light fixture was suspended from the ceiling in each room with a small fan adjacent to facilitate room air mixing.

\section{RESULTS AND DISCUSSION}

The analysis can be significant difference UVCaromatherapy treatment against impairment of the germs Tb Lung Positive Patients $(p=0,026)$. This is, to our knowledge, first controlled evaluation of the effect of upper-room UV light or negative air ionization on airborne TB transmission in a clinical setting. On the basis of laboratory evidence of mycobacterial susceptibility to UV light [13], the effects of UV lamps on mycobacterial aerosols the U.S. Centers for Disease Control and Prevention recommends upper-room UV light as an environmental control measure for $\mathrm{TB}$ in health care settings [14].

However use is not widespread, owing primarily to the lack of studies in a clinical setting. Upperroom UV in a hospital waiting room reduced airborne bacteria, but TB transmission was not investigated due to the logistical difficulties such studies entail [15]. The efficacy of UV light demonstrated in the current study has important implications for TB infection control, especially in low-resource settings, where the burden of TB is highest. Upper-room UV light is a relatively lowcost intervention compared with mechanical ventilation. Furthermore, it is ideally suited to overcrowd congregate settings such as waiting rooms, outpatient and emergency departments, or anti-retroviral treatment facilities.

Previously reported cases of over-exposure resulted from incorrect lamp installation or inadequate action if a UV bulb became unshielded [16]. Expert installation of upper-room UV systems is, therefore, imperative, with post-installation checking of UV fields to ensure there is no excess UV light reflected downwards. Indeed following lamp installation in this study, bulbs required additional baffles and the ceiling was painted matt to reduce reflections. No adverse UV effects were reported by patients or staff, and staff and patient exposures measured with the personal UV meter were within permitted levels. This concurs with other recent data concerning upper-room UV safety [17]. TB infection control is a global public health priority owing to the epidemic, and to the importance of nosocomial transmission in the propagation of multi- and extensively drug-resistant strains. The expansion of care, entailing congregation in overcrowded settings of highly susceptible persons with those most likely to have $\mathrm{TB}$, accentuates the need for effective prevention of TB transmission. Upper-room UV light is an effective and relatively low-cost environmental control measure already recommended as an adjunctive measure by guidelines but little used owing to the lack of studies in clinical settings until now [18]. 


\section{CONCLUSION}

Upper-room UV has great potential for $\mathrm{TB}$ infection control in settings where climate does not permit the use of natural ventilation or for use in cooler winter months, or at night when windows are likely to be closed. Efforts should be made to design simple UV fixtures for low-resource settings. Negative air ionization is a novel infection control strategy warranting further investigation. These environmental control measures are well suited to large congregate settings such as waiting rooms or emergency departments, where $\mathrm{TB}$ is often undiagnosed, overcrowding is common, and respiratory isolation facilities are frequently unavailable.

UVC-aromatherapy can be used as a form of treatment Positive Patients with Pulmonary Tb, which can sync yours with pulmonary $\mathrm{Tb}$ program in the Department of Health. Minimize dependency on the use of drugs and prevent dropouts and resistance problems

\section{REFERENCES}

[1] Kementerian Kesehatan RI (2007) Buku Panduan Pos TB Desa. Direktorat Jenderal Pengendalian Penyakit Dan Penyehatan Lingkungan. Jakarta: Depkes RI.

[2] Gandhi NR, Moll A, Sturm AW, Pawinski R, Govender T, et al. (2006) Extensively drug-resistant tuberculosis as a cause of death in patients coinfected with tuberculosis and HIV in a rural area of South Africa. Lancet 368: 1575-1580.

[3] Mohle-Boetani JC, Miguelino V, Dewsnup DH, Desmond E, Horowitz E, et al. (2002) Tuberculosis outbreak in a housing unit for human immunodeficiency virus-infected patients in a correctional facility: transmission risk factors and effective outbreak control. Clin Infect Dis 34: 668-676.

[4] Catanzaro A (1982) Nosocomial tuberculosis. Am Rev Respir Dis 125: $559-562$.

[5] Valway SE, Greifinger RB, Papania M, Kilburn JO, Woodley C, et al. (1994) Multidrug-resistant tuberculosis in the New York State prison system, 1990-1991. J Infect Dis 170: 151-156.

[6] Pai M, Kalantri S, Aggarwal AN, Menzies D, Blumberg HM (2006) Nosocomial tuberculosis in India. Emerg Infect Dis 12: 1311-1318.

[7] Escombe AR, Oeser CC, Gilman RH, Navincopa M, Ticona E, et al (2007) Natural ventilation for the prevention of airborne contagion. PLoS Med 4: e68. doi:10.1371/journal.pmed.0040068

[8] Nardell EA, Keegan J, Cheney SA, Etkind SC (1991) Airborne infection. Theoretical limits of protection achievable by building ventilation. Am Rev Respir Dis 144: 302-306.

[9] WHO. (2011) Global Tuberculosis Control; WHO Report 2011. World Health Organization. Geneva.

[10] Kemenkes RI. (2010) Riset Kesehatan Dasar. Badan Penelitian Dan Pengembangan Kesehatan.

[11] Dinas Kesehatan Propinsi Kepri. (2012) Profil Dinas Kesehatan Provinsi Kepulauan Riau. Provinsi Kepulauan Riau.

[12] Dinas Kesehatan Kota Tanjungpinang. (2012) Profil Dinas Kesehatan Kota. Dinas Kesehatan Kota Tanjungpinang. Provinsi Kepulauan Riau.

[13] Riley RL, Nardell EA (1989) Clearing the air. The theory and application of ultraviolet air disinfection. Am Rev Respir Dis 139: $1286-1294$.

[14] Xu P, Peccia J, Fabian P, Martyny JW, Fennelly KP, et al. (2003) Efficacy of ultraviolet germicidal irradiation of upper-room air in inactivating bacterial spores and Mycobacteria in full-scale studies. Atmos Environ 37: 405-419.

[15] Macher JM, Alevantis LE, Chang YL, Liu K (1992) Effect of ultraviolet germicidal lamps on airborne microorganisms in an outpatient waiting room. Appl Occup Environ Hyg 7: 505-513.

[16] Brubacher J, Hoffman RS (1996) Hazards of ultraviolet lighting used for tuberculosis control. Chest 109: 582-583.

[17] Nardell EA, Bucher SJ, Brickner PW, Wang C, Vincent RL, et al. (2008) Safety of upper room ultraviolet germicidal air disinfection for room occupants. Public Health Rep 123: 52-60.

[18] Xu P, Kujundzic E, Peccia J, Schafer MP, Moss G, et al. (2005) Impact of environmental factors on efficacy of upper-room air ultraviolet germicidal irradiation for inactivating airborne mycobacteria. Environ Sci Technol 39:9656-9664. 